Schulich School of Law, Dalhousie University

Schulich Law Scholars

Research Papers, Working Papers, Conference

Papers

Faculty Scholarship

7-4-2017

\title{
Education as a Basic Human Right: A Response to Special Education and the Charter
}

\author{
A. Wayne Wayne MacKay \\ Dalhousie University - Schulich School of Law, wayne.mackay@dal.ca \\ Gordon Krinke \\ Dalhousie University, Author2739167@ssrn.com
}

Follow this and additional works at: https://digitalcommons.schulichlaw.dal.ca/working_papers

\section{Recommended Citation}

MacKay, A. Wayne Wayne and Krinke, Gordon, "Education as a Basic Human Right: A Response to Special Education and the Charter" (2017). Research Papers, Working Papers, Conference Papers. 12.

https://digitalcommons.schulichlaw.dal.ca/working_papers/12

This Working Paper is brought to you for free and open access by the Faculty Scholarship at Schulich Law Scholars. It has been accepted for inclusion in Research Papers, Working Papers, Conference Papers by an authorized administrator of Schulich Law Scholars. For more information, please contact hannah.steeves@dal.ca. 


\title{
Education as a Basic Human Right: A Response to Special Education and the Charter
}

\author{
A.Wayne MacKay and Gordon Krinke \\ Faculty of Law \\ Dalhousie University
}

"Special Education and the Charter: The Right to Equal Benefit of the Law" is an excellent article on the provincial statutory regimes and their relationship to s. 15 of the Charter. It surveys the legislatures' attempts at delivering education to students and highlights the shortcomings in these attempts, focussing on the inability or unwillingness of the legislatures to provide an appropriate education to mentally disabled individuals. The article then takes a prospective approach, illustrating how a generous interpretation of s. 15 of the Charter might be used to correct deficiencies in educational statutes. Both the survey of statute law and the commentary on its relationship to the equality provisions of the Charter provide a valuable addition to scholarly writing on the provision of appropriate education to the mentally disabled.

However, there is some danger in assuming that the right to education derives solely from statute. Statutes are creations of legislatures. If the right to education exists only in these statutes, education may be viewed not as the right of every child, but as a privilege bestowed by the legislature, to be determined by administrators, and to be overseen only as a last resort by the courts. The danger is emphasized emphasized by the comment of Lloyd Gillis, Chief Executive Officer of the Halifax County-Bedford School District, following the settlement reached in the Elwood ${ }^{1}$ case:

One of the issues [in recent litigation] was who should have the right to make the final decision. As a body corporate established under a provincial statute, our mandate is to provide [education], so it is our right to decide where and how it should be provided. ${ }^{2}$

It would be preferable to view education as a basic human right with the 
legislature providing the mechanism by which the right is exercised. This view of education would attract a more activist stance by the courts, and would allow minority groups, particularly the mentally disabled, greater access to education as well as more input toward determining what is an appropriate education.

\section{Education as a Human Right}

Students' rights have come under closer scrutiny in the past fifteen years. However, while the students' rights movement has been primarily concerned with the rights individuals have in the classroom, the emphasis is different for those who are mentally disabled. For these individuals, the focus of any rights discussion is on access to the educational system and, once access has been gained, education in the most appropriate setting. The right of the mentally disabled to the most appropriate education is presently the focus of most of the litigation concerning the right to an education, and it is in this context that a right to education apart from statute will most probably be articulated by the court.

The Canadian public as a whole, and the courts specifically, are becoming more rights conscious. However, this development has led many lawyers and judges into unexplored areas. In a recent address, Mr. Justice Bayda of the Saskatchewan Court of Appeal compared lawyers and judges to mechanics. ${ }^{3}$ These legal mechanics are more interested in the how and what of a case, with little use for the why. However, if the concept of rights is to develop in Canada, arguments must be framed in terms of why the right should exist and why a particular group is entitled to the right.

What moral arguments can be made concerning the right to education? How can it be justified? Pennock lists five means: ${ }^{4}$ First, rights can be justified through intuition. They may be "self-evident" as stated in the American Declaration of Independence, or "re-affirmed" as stated in the Universal Declaration of Human Rights, ${ }^{5}$ or derived "from the inherent dignity of the human person," as in the International Covenant on Economic, Social and Cultural Rights. ${ }^{6}$

Few, however, would argue that intuitively there is a right to education. Still fewer would feel comfortable using this argument in court, despite the inclusion of the right to education in most modern human rights declarations. The explanation for this is, in large part, conditioned by a particular view of human rights as "negative" rather than "postive." The concept of human rights arose in the eighteenth-century as a reaction to feudal/absolutist states and received a renaissance following, and largely as a result of, the horrors of World War II. During these periods, the state was viewed as the enemy and the concept of human rights largely as one of protecting the individual from the state. While this view is still valid, the concept of human rights has expanded to reffect changes in modern societies.

A modern definition of human rights recognizes the different forces which have shaped present-day society. The Universal Declaration of Human Rights, for instance, has been called "a synthesis of eighteenth-century individualism and nineteenth-century socialism." dynamics which have shaped modern Canadian society. Education, commonly referred to as a "welfare" right, a right which makes claims on the government, fits within this new concept of human rights. If rights are viewed from this new perspective, it seems fitting to talk of a basic human right to education.

A second means of justifying a right to education is by employing the "social contract" theory. Under this theory, "the individual gives up much of his [her] autonomy to majority rule and representative government. But every individual retains some of his/her original autonomy as rights, even against the people and their representatives. ${ }_{8}$

The question becomes what is the basis of the contract between the people and the government. Certain enumerated rights have been included in the Charter and surely form part of the written contract. ${ }^{9}$ By design, these rights are stated in terms not easily defined. The burden of giving content to them is placed on the judiciary. Section 7 of the Charter, which acknowledges an individual's right to "life, liberty and security of the person," is the logical place to find the right to an appropriate education.

However, an argument can be made that welfare rights, particularly the right to education, are part of the unwritten contract which for so long has been a part of the English common law tradition. The right to the use or enjoyment of property, for example, has for centuries been an unwritten, but judicially recognized, right. ${ }^{10}$

The justifications for a right to property are compelling. Pennock lists four:" First, property is essential to a person's sense of identity and human dignity, including self-respect; second, property is a concrete indication of a person's work and accomplishments; third, property appears to be essential to society; finally, ownership of property provides freedom. However, these same justifications are no less compelling when applied to a right to education in a modern society. Education, too, provides a sense of identity and self-respect; it is a measure of a person's accomplishments; it is essential to society and a means of providing freedom. Indeed, information has come to be regarded as a new form of property, and in the United States the courts have recognized access to information as a fundamental interest. ${ }^{12}$

A third means of justifying a right to education is by referring to societal conventions. If one looks at the history of education, it is evident that the government has usurped what was once the domain of parents and private institutions. ${ }^{13}$ Following the industrial revolution, the state realized the importance of an educated populace, and parents acknowledged the limits on their ability adequately to educate their children. The education system developed into a state-financed and controlled institution. The end result is that "the government has acquired a virtual monopoly on the dissemination of information to children of compulsory schooling age." 14

The state's long-standing commitment to education has increased parents' reliance on public education, and no one now would seriously contend that parents could reassert their previous authority to control personally their child's education. This factor, coupled with the importance of education to both the student 
and the state, suggests that education is one societal convention which should be considered as a right. The symbiotic nature of education is illustrated by the views of John Stuart Mill, for whom:

... educability meant that men, women and children are susceptible to influences which assist their growth towards goals which are deemed worthwhile, whether happiness, freedom, or any others; that they can be initiated into existing values and thus contribute to society's permanence and cohesion; and that they can be raised to higher levels of experience, to an improved quality of life, thus contributing to social progress and human betterment. From it there follows inevitably a commitment to education as a prime instrument in the creation and development of a democratic society-education not as the privilege of a few, but as the right and the obligation of all. ${ }^{15}$

A fourth means of justifying the right to education considers the relationship between duties and rights. If citizens have duties in society, they must have certain rights to enable them to fulfill these duties. These obligations are both legal and moral. Politically, they include keeping informed, participating in the political process and exercising the political rights guaranteed under the Charter. Social duties include acquiring and transmitting accepted cultural values as well as respecting the values of others. Individuals should also maximize their potential in the work force as well as setting worthwhile goals and attempting to fulfill these goals. It is difficult to conceive of an individual carrying out these duties without first being educated.

Finally, a right to education can be justified by demonstrating its value in promoting those requirements which ensure human happiness. While "happiness" is a vague term, Pennock lists two requirements, rationality and dignity, ${ }^{16}$ and Gewirth lists a third, freedom, ${ }^{17}$ as essentials to happiness. Education promotes freedom. Economically, it expands the range of options open to individuals. Politically, as Brougham commented "... it makes a people easy to lead, but difficult to drive; easy to govern, but impossible to enslave." Metaphysically, as Epictetus stated: "Only the educated are free."

Education also promotes dignity by increasing self-esteem and self-reliance:

To be reduced to life-long dependence on the support of others, howevereven supposing this to be forthcoming-might itself be regarded as an unacceptable humiliation and therefore as a harm from which the individual is entitled to protection. ${ }^{18}$

Finally, education promotes rationality. One goal of education is to produce rational individuals. Education should produce an individual who "feels that the universe is, on the whole, a sensible, reasonable and trustworthy place," as opposed to those less rational who view the world as "senseless, unpredictable and treacherous," never knowing "what may happen, particularly in a new situation, except that it will probably be bad." 19
A right to education can be justified. However, such a right must be "positivized," it must be translated into legal terms:

That means that [it] must be cast in a form which can generate both effective executive action and a basis for legal argument concerning [its] violation. Beyond this, many rights require state commitment to, and finance for, definable policy objectives, particularly in cases where a right is required to be facilitated by law or involves significant state funding. ${ }^{20}$

There is a danger in positivizing human rights. When human rights are translated into legal rights, they are often limited, either by employing restrictive definitions of the right or by allowing significant exceptions to exist. This, of course, is confirmed by Sussel and Manley-Casimir's review of existing statute law, which indicates the right to education has been limited. The right to education is defined as the right to "attend" or to be "reasonably accommodated" by the schools. Moreover, it is not the right of everyone. Numerous limitations apply, particularly concerning the mentally disabled who, it can be safely said, are the target of those exceptions which eliminate individuals who cannot "profit" from the classroom.

The provincial legislatures have thus become, "the necessary friend, as well as the recurrent enemy" 21 of an individual's right to education. Of the three branches of government entrusted solely with creating law, it would be preferable that the legislatures rectify the problem. But this is not likely to occur, especially in the area of providing the right to education to minority groups such as the disabled, for

... states have a legitimate interest in the welfare of the majority of their inhabitants and are in a position to make plausible claims to the effect that they must sometimes sacrifice the interests of minorities to the general good. ${ }^{22}$

Parents of mentally disabled children are turning not to the legislatures, but to the courts to redress the wrong. A liberal application of section 15 of the Charter is one fruitful avenue, one which has been explained in excellent fashion by Sussel and Manley-Casimir. A second avenue, however, does exist. This is the focus of the next section.

\section{A Judicially Recognized Right to Education}

A judicially recognized right to education apart from statute would involve the courts in a legislative role which, although not unfamiliar, is uncomfortable. There is no question that judges make law. As Lord Radcliffe said, ". ... there was never a more sterile controversy than that upon the question of whether a judge makes law. Of course he does." 23 The controversy, however, extends to the ambit of the court's legislative ability and the normative question of whether judges should make law.

The parameters of the court's legislative ability extends from the restrictive to 
the expansive. Mr. Justice Dickson, in Harrison v. Carswell, indicates that a judge "... is not a knight-errant, roaming at will in pursuit of his own ideal of beauty or goodness. He is to draw his inspiration from consecrated principles," 24 concluding with a familiar statement that judges must legislate, but that "they are confined from molar to molecular motion." 2.5

At the other end of the spectrum, Denning stated:

I know that over 300 years ago Hobart C. J.said the 'Public policy is an unruly horse'... So unruly is the horse, it is said, that no judge should ever try to mount it lest it run away with him. I disagree. With a good man in the saddle, the unruly horse can be kept in control. ${ }^{26}$

It is likely that Canadian courts will follow a middle path, but the judicial trend appears to be more interventionist. In Re s. 94(2) of the Motor Vehicle Act (B.C.), Mr. Justice Lamer recognized that the Charter had extended the scope of judicial review in constitutional matters to " ... the rights of individuals as well as the distribution of powers. "27 Lamer justified increased judicial activism by noting that the entrenchment of the Charter was undertaken by the elected representatives of the people. By doing so, the legislatures chose to relinquish some of their powers and to vest in the judiciary the protection of rights.

It is not possible to answer this question in so short a space. However, certain criticisms leveled at the legislative capacities of the courts should be briefly examined, specifically as they relate to the establishment of a right to education. The first criticism centres around the undemocratic nature of the judiciary. Judges, because they are appointed officials and hold office for life, are not accountable. However, arguments can be made to counter this criticism. First, the entire question of human rights is, if not undemocratic, at least contramajoritarian. Rights are guaranteed regardless of the wishes of the majority. Second, legislatures are sensitive to the needs of the majority and/or the powerful:

There are some areas of the law where legislative action is superior to judicial action, for example in corporate and commercial law. Those directly affected by the legislation are in close and constant communication with the legislator. They form a powerful lobby group.... But the legislative process can be a slow and cumbersome one and many areas of the law which badly need reform may simply be low priority, not politically profitable. The legislative process should not be idealized out of all proportion. ${ }^{28}$

As can be seen by the frustration with which parents of disabled individuals regard the legislative process, this criticism is valid. The mentally disabled have been called the silent minority. ${ }^{29}$ They lack power. Recognition of a right to an appropriate education is not politically profitable. If the legislatures will not act to protect the right to education, the judiciary is the only alternative.

A second criticism concerning the court's legislative capacity is the judge's lack of expertise. Judges are a group isolated from society. They have essentially the same background and training. Few have backgrounds in education. As well, judges are more constrained in their ability to acquire knowledge. They must, with few exceptions, deal with only those facts presented in the case before them; as well, they lack the bureaucracy which the legislative branch has built up to gather and assess data.

In the area of rights, however, this criticism is less compelling. Traditionally, the courts have been perceived as the defender of rights, and the courts, not the legislatures, have the expertise. Moreover, the question of rights is not a statistical but a moral question. No amount of information gathering and no amount of analysis can change the basis of rights.

On rights issues, the courts are the logical forum. Judges are viewed as impartial and apolitical. While few believe this to be entirely true, ${ }^{30}$ the judiciary, because of this common perception, is more subject to self-imposed constraints. In the early 1980 s, when the regional structure of the Supreme Court of Canada was being considered, some individuals implied that Supreme Court justices decided certain cases according to their backgrounds. Laskin C. J. C. responded to this criticism:

It saddened me that there was so little understanding manifested either about the nature of the Court's work or about the significance of the fidelity of its members to their oaths of office, so little appreciation of the importance of cohesion and collegiality in the dispatch of the Court's work. That work has no regional and certainly no political tie-in. ${ }^{31}$

A third criticism of judge-made law is its retrospective nature. Bentham summed up this argument:

Do you know how [judges] make [law]? Just as a man makes law for his dog. When your dog does anything you want to break him of, you wait till he does it and then beat him. This is the way you make laws for your dog, and this is the way the judges make law for you and me. ${ }^{32}$

This criticism is certainly valid. A judicial creation of a right to education will alter the relationship between educational authorities and individuals retrospectively. In an area already heavily legislated, this must be carefully considered. At the same time, legislatures do not appear willing to extend the right to appropriate education to the mentally disabled. Moreover, any such legislation is subject to the frailties which exist in present-day statutes.

Education authorities have had considerable waming. Canada, as a signatory to various international conventions recognizing the right to education, has made a commitment. ${ }^{33}$ As well, the Charter, now in existence for five years, should have caused legislators and education administrators to evaluate the education structure. Indeed, many scholars perceive the Charter's most salutary effect as establishing a standard to which officials will conform. ${ }^{34}$ Having failed to meet this standard, and having refused to fulfill their international commitments, educators should not be surprised when the courts intervene.

One final criticism concerns judicial creation of "welfare" rights such as the right to education. Once judges create such a right, they are not responsible for its implementation. No one doubts that a right to an appropriate education, 
especially as it regards the mentally disabled, will result in a re-allocation of resources. In Elwood, for example, the School Board mentioned:

If through this litigation it is determined that the parents of a mentally disabled child have the legal right to have their child educated in the classroom of their choice, it would then be necessary for the School Board to develop a new system of education for disabled children. ${ }^{35}$

There is no way to deny the validity of this argument. In the end, it is a weighing process. What benefits will be achieved against what costs to society? The importance of education, our re-affirmation of rights and our concept of an egalitarian society suggest that the benefits outweigh the costs.

The courts have in the past used, and may in the future use, the above criticisms of judge-made law to deny their ability to be creative. Proponents of a right to education for all, including the mentally disabled, may be told that the issue is a political one, and one which would best be solved by political pressure. One can hope that this is not the result. A better alternative is a judicially established right to education, acknowledging that:

Where the interest governed by the legislation is substantial, and the government action proposed would inflict more than de minimis harm, the judiciary cannot continue counselling plaintiffs to rely on the political process to vindicate their interests. ${ }^{36}$

Prior to the coming into existence of the Charter, a judicially recognized right to an appropriate education would have to be found at common law. But, as Sussel and Manley-Casimir point out, such a common law right to education remains to be articulated. While this avenue is still open, it would be a large step for the courts to take. The more likely alternative is a judicially recognized constitutional right to an appropriate education.

\section{A Constitutional Right to Education}

Section 15 of the Charter is one constitutional avenue which the mentally disabled are travelling toward their goal of achieving an appropriate education. Sussel and Manley-Casimir's article pursues this avenue, and it is not the subject of this section. However, the courts can find discrimination under s. 15 without first finding that a right to education exists since $s$. 15 dictates that once a benefit is provided to some, it must be provided to all. The benefit need not be a right.

The constitutional right to education in the Charter must be found elsewhere, most logically in s. 7:

Everyone has the right to life, liberty and security of the person and the right not to be deprived thereof except in accordance with the principles of fundamental justice.

Judicial recognition of the right to education under s. 7 of the Charter carries several benefits. The Canadian Charter of Rights and Freedoms, being the "supreme law of the land," ${ }^{37}$ is superior to statutes. Education provisions in statutes and regulations which do not conform to Charter standards are of no force and effect. Under s. 24(1), the court can order a remedy which it deems fit to correct a violation. While some violations can be saved by using s. 1 , the onus of proving the violation as a "reasonable limit" is placed on the government (school board). The school board would be held to "a stringent standard of justification." ${ }^{8}$ Should the right to education be found in s. 7, the school board could not deprive an individual of this right except in accordance with fundamental justice This standard is much more onerous than a standard of "fairness," and denotes both procedural and substantive review. ${ }^{39}$ Finally, while the possibility exists that the Charter's override provision, s. 33, could be used to exempt education authorities from conforming with Charter provisions, any such attempt would, at a minimum, bring the controversy into the realm of public debate. This quite possibly would serve to highlight the inequitable position of the mentally disabled in the education system.

Although the Charter has been in effect for five years, Canadian jurisprudence on a constitutional right to education is scanty. Because of this, the courts will generally turn to the United States first when examining this issue. While some lower courts in the United States have seemingly recognized education as a constitutional right, ${ }^{40}$ the United States Supreme Court has rejected this claim. ${ }^{41}$ This should not, however, be definitive of the issue.

First, there is a difference in the wording of the two documents. Section 7 of the Charter is positive: "Everyone has the right to life, liberty and security of the person. ..." The 14th Amendment to the American Constitution is negative:

No State shall make or enforce any law which shall abridge the privilege or immunities of citizens of the United States; nor shall any State deprive any person of life, liberty, or property without due process of law...

A strong argument can be made that the difference is not mere semantics. A positive right invites state action.

Second, the structure of the two documents is different. Lamer J. in $R e s$. 94(2) of the Motor Vehicle Act (B.C.) highlights three differences between the Charter and the American Constitution. There is no equivalent of s. 52, the supremacy clause, in the American Constitution. ${ }^{42}$ This gives the Canadian courts more authority to be activist. As well, there is no equivalent of s. 33, the override provision. This is especially significant in the area of rights. One criticism of judicial activism is the possibility of contramajoritarian reform. However, through s. 33, legislatures could alter any judicial reform by "opting-out." Finally, the U.S. Constitution has no equivalent for the Charter's s. 1, "reasonable limits" clause. This, too, is significant. With no means of limiting the right, the United States' courts have been reluctant to expand the content of substantive rights.

Finally, "human rights documents should be placed in their historical and contextual setting." 43 The Charter is a modern document; the U.S. Constitution is significantly older. The Charter was crafted in the context of the strengths and 
weaknesses of the United States rights jurisprudence as well as the disappointing Canadian experience with the Bill of Rights. It was also the result of politica compromises leading up to its passage in $1982 .^{44}$ There is no doubt that it was meant to be remedial, and earlier decisions regarding educational rights, both in the United States and Canada, must be read in that light. As well, Canadians have different values than Americans. There is a danger in linking Charter jurisprudence to United States jurisprudence. In the area of education rights, Canada may well be more progressive than her southern neighbour.

Strong arguments can be made to support the inclusion of the right to education in the Charter. The Charter was drafted after Canada had committed itself in the international arena to granting a right to education. While Canada is not bound by international law, and these documents have no legal impact in Canada, a reading of the Charter should be made to conform as much as possible to these commitments.

Two sections of the Charter, s. 23 (minority language education) and s. 29 (rights to denominational schools), mention education specifically. To grant a right to be educated in a minority language or in a separate school, but to refuse to recognize a pre-existing right to education, "would be offering a vehicle but denying roads and destinations." 45

Other Charter rights, notably the s. 2 fundamental freedoms of conscience, religion, thought, belief, opinion, expression, peaceful assembly, and association, would be rendered ineffectual without a pre-existing right to education. Surely the right to vote and the right to be qualified as member of the House of Commons or of a legislative assembly (s. 3) are rendered ineffectual without a preexisting right to an education. In Switzman v. Elbling, Rand J. commented:

Whatever the deficiencies in its workings, Canadian government is in substance the will of the majority expressed directly or indirectly through popular assemblies. This means ultimately government by free public opinion of an open society....

But public opinion, in order to meet such a responsibility, demands the condition of a virtually unobstructed access to and diffusion of ideas. Parliamentary government postulates a capacity in men, acting freely and under self-restraints, to govern themselves, and that advance is best served in the degree achieved of individual liberation from subjective as well as objective shackles. ${ }^{46}$

Without an education, a person's access to ideas is blocked, his capacity to govern, indeed, his capacity to take advantage of his rights is diminished. A denial of a person's right to education would place shackles on any citizen in modern Canadian society.

Should the right to education be included as part of "life, liberty and security of the person"? The answer can be found by looking at human rights theory as well as judicial pronouncements. Blackstone, in his Commentaries, mentioned as the first right of English law the right to personal security. Included in this right "were a person's legal and uninterrupted enjoyment of his life, his limbs his body, his health and his reputation." ${ }^{47}$ The security of a person's reputation is important "since without it, it is impossible to have the perfect enjoyment of any other advantage or right." ${ }_{48}$ In modern society, a lack of education affects detrimentally a person's reputation. More specific to the mentally disabled, the placement in a segregated setting increases this harm for

Experts agree that it is primarily the school which imposes the mentally retarded label and concomitant stigmatization upon children, either ini-

tially or later on through a change in educational assignment. ${ }^{49}$

Parents have likened this stigmatization to "a sentence of death." 50

Pennock acknowledges that the human right to "life" has an experiential com. ponent. ${ }^{5 t}$ The meaning of life must be extended to include the conditions for purposive behaviour. Therefore, everyone must have the ability to select ends and means and the freedom to do so. Closely tied to these are a person's sense of dig. nity. Education enhances dignity, provides the freedom to make choices and increases one's ability to make knowledgeable decisions.

Gewirth takes another approach. ${ }^{52}$ For him, persons have rights to the necessary conditions of action since all moral precepts are concerned directly or indirectly with how persons ought to act. The two components of action are freedom and well-being. Well-being includes life, physical integrity and mental equilibrium. Certain conditions are required for increasing one's well-being, including a heightened sense of self-esteem and an education to the limits of one's capacities. As education is also necessary to provide for a person's freedom to control his actions and participate in transactions by his/her unforced choice or consent, it is essential to liberty.

Finally, Jones recognizes two components to the meaning of liberty. It can "connote either a situation in which the individual is free from external restraint or a situation in which the individual is able, or enabled, to realize his potentialities and aspirations." ${ }_{53}$ Often the two components conflict. For example, compulsory education is, according to the first component, a denial of liberty while, according to the second component, a means of achieving liberty.

In addition to human rights theory, there are judicial dicta to support the establishment of education as a constitutional right under s. 7 of the Charter. The latest Supreme Court decision to discuss $\mathrm{s} .7$ in the context of education is $R$. $v$. Jones. Both the majority and minority quoted from Meyer $v$. Nebraska ${ }^{54}$ when searching for a definition of "liberty":

Without doubt, it denotes not merely freedom from bodily restraint, but also the right of the individual to contract, to engage in any of the common occupations of life, to acquire useful knowledge, to marry, to establish a home and bring up children, to worship God according to the dictates of his own conscience and generally to enjoy those privileges long recognized at common law as essential to the orderly pursuit of happiness by free men. ${ }^{s s}$

The majority felt, on the facts of the case, it did not need to comment on the 
meaning of liberty or security of the person. It is significant that it did not reject the broad definition of liberty. Madame Justice Wilson, in dissent, adopted the broad American statement. Moreover, certain of her comments may be indicat ive of the court's approach to liberty. She began by commenting:

In deciding what rights are included in the definition of liberty, it is helpful, therefore, to remind ourselves that liberty in our Charter means liberty as understood and enjoyed in a free and democratic society. ${ }^{56}$

She concludes with a definition of liberty which would be large enough to encompass the right to an appropriate education:

I believe that the framers of the Constitution in guaranteeing "liberty" as a fundamental value in a free and democratic society had in mind the freedom of the individual to develop and realize his potential to the full, to make his own choices for good or ill, to be non-conformist, idiosyncratic and even eccentric - to be, in today's parlance "his own person" and accountable as such. ${ }^{57}$

Both human rights theory, and judicial dicta support the inclusion of the right to an appropriate education in s. 7 of the Charter ${ }^{58}$

In a recent Supreme Court case, Eve ${ }^{59}$ the court was perceived as creating a new right, the right to procreate. While the creation of this right has been criticized, the criticism has been leveled largely against the court's failure to provide an adequate rationale rather than against its ability to legislate. The case highlights two relevant factors: first, it demonstrates the court's willingness to articulate rights for the first time. Second, it illustrates the court's role as defender of the rights of those least able to defend themselves.

In the course of his decision, La Forest $J$. made two comments which are especially applicable when dealing with the rights of the mentally disabled to an appropriate education. He first acknowledged that the decision concerning sterilization of Eve "... involves values in an area where our social history clouds our vision and encourages many to perceive the mentally handicapped as somewhat less than human." ${ }^{60}$ He later stated that "... the fact that others may suffer inconvenience or hardship from failure to [authorize the operation] cannot be taken into account. The Crown's parens patriae jurisdiction exists for the benefit of those who cannot help themselves, not to relieve those who may have the burden of caring for them." 61

The same comments are valid concerning the mentally disabled and their struggle for an appropriate education. The area is fraught with myths and misconceptions. Decisions which deny the mentally disabled an appropriate education are ostensibly taken for the benefit of the disabled while, in reality, they simply ease the burden on others. If the courts can be persuaded that there exists a suitable foundation for the creation of a right to education, the court may offer the mentally disabled this protection for the first time.

There is a suitable foundation upon which to establish such a right. In addition to the strong arguments used to justify education as a basic human right, there are judicial pronouncements which aid the case ${ }^{62}$ Judicial reasoning closely parallels human rights theory - and the Charter brings the two together.

\section{The Content of the Right to Education}

To say that an individual has a right to education without giving some content to the right is to leave the task unfinished; to grant an individual the right to education but leave the definition of education in the hands of education authorities is to render the right nugatory. While acknowledging that the details of education are the domain of educational experts, it is possible to define the general content of a right to education.

The first step in defining the content of the right to education is to specify the proper goals of education. These will affect the answers to such important practical questions as who should have access to the educational system. If, for example, education is defined mainly as the transmission of technical academic and vocational skills, then those who cannot "profit" from such "education," can be denied access. If, on the other hand, the purpose of education is not only to impart information but to socialize the student, the right of access will be much wider.

Modern human rights documents establish the goals of education as something far removed from mere academic training. The International Covenant states:

.. education shall be directed to the full development of the human personality and the sense of its dignity, and shall strengthen the respect for human rights and fundamental freedoms....

education shall enable all persons to participate effectively in society, and promote understanding, tolerance and friendship among all nations and all racial, ethnic, or religious groups. ${ }^{63}$

Education statutes (and documents prepared under them) also treat education as a means of developing the entire individual. For example, the Education Act ${ }^{64}$ in Nova Scotia mentions several duties of teachers, two of which are relevant here. First, teachers must "teach diligently the subjects and courses prescribed." The courses, as listed in the Program of Studies, include academic courses (mathematics, physics, etc.), but also include courses such as music, physical education and health designed to create a rounded individual. Second, teachers are to "encourage in the pupils... respect for religion and the principles of Christian morality, for truth, justice, love of country, humanity, industry, temperance and all other virtues. " ${ }_{65}$ The goal of education is much more than to create scholars. Indeed, a major aspect of compulsory attendance provisions in education statutes is that schooling has become the compulsory path of socialization in Canada.

Judicial pronouncements also treat the goals of education as much more than mere imparting of information. In Brown v. Board of Education, the United States Supreme Court declared, 
Today, education is perhaps the most important function of state and local governments. Compulsory school attendance laws and the great expenditures for education both demonstrate our recognition of the importance of education to our democratic society. It is required in the performance of our most basic public responsibilities, even good citizenship. Today, it is a principal instrument in awakening the child to cultural values, in preparing him for later professional training, and in helping him to adjust normally to his environment. In these days, it is doubtful that any child may reasonably be expected to succeed in life if he is denied the opportunity of an education. ${ }^{66}$

That interaction with peers and adults, not content, is one of the most impor tant benefits of education is reflected in the writings of educational theorists. Holt, for example, states: "It is not the subject matter that makes some learning more valuable than others, but the spirit in which the work is done." ${ }^{67} \mathrm{He}$ later states that society must have

.. schools and classrooms in which each child in his own way can satisfy his curiousity, develop his abilities and talents, pursue his interests, and from adults and older children around him get a glimpse of the great variety and richness of life. ${ }^{68}$

The goals of modern education are holistic. They are meant to create an individual who has a sense of self-worth and the worth of others, an individual who can participate in a variety of communities, local, national and international, an individual who is comfortable with himself and others. The right to education must include programs and an environment which accomplishes those goals to the greatest extent possible.

Presuming that all children are allowed access to the educational system, what input should they have as to where they are placed? Most students have access to the age-appropriate class at the neighbourhood school. Should similar access be accorded the mentally disabled? Judicial decisions prior to the coming into force of the Charter indicate that mentally disabled students need not be provided such access. ${ }^{69}$ The Charter may change this. Under s. 15 , mentally disabled students cannot be discriminated against. A benefit provided to some must be provided to all. Are there some benefits to being placed in the "normal" class? If mentally disabled students are placed in the "normal" class, should they be provided with additional resources? This question, which entails defining the meaning of equality, is the focus of much of the Sussel and Manley-Casimir article. However, the matter can also be discussed as a part of the right to education under s. 7 . If the goals of education are defined in terms beyond the academic, and a segregated classroom denies mentally disabled students the means of obtaining these goals, segregation is a violation of the substantive s. 7 right.

Mainstreaming is the educational equivalent of a broader concept concerning the treatment and placement of the mentally disabled, that of normalization. This theory stresses that the mentally disabled be provided with an experience which resembles, as closely as possible, the cultural norm. At its most ambitious, mainstreaming is "an integration of regular and exceptional children in a school setting where all children share the same resources and opportunities for learning on a full-time basis."

Mainstreaming is designed to help individuals academically, psychologically and socially. Academically, mainstream environments are considered to be more challenging and more stimulating than segregated environments. Psychologically, interaction with so"called "normal" peers increases an individual's sense of self-esteem. Socially, the stigma resulting from being labelled "special ed." is eliminated when mentally disabled individuals are mainstreamed. Another advantage to mainstreaming is the change in perception by other students and teachers about disabled individuals.

Whether mainstreaming in fact leads to those results is another question. There has simply been a lack of adequate research:

After more than a decade of promoting normalization it remains a basically ephemeral construct, backed by relatively little sound research. The characteristic of normalization as "a banner in search of some data" is still a fair one. ${ }^{7 !}$

Biklen acknowledges the problems and difficulties with the research, but states that "The question of whether or not to promote mainstreaming is not essentially a question for science. It is a moral question. It is a goal, indeed, a value to pursue or reject on the basis of what we want our society to look like."72

While the education authorities' willingness to embrace mainstreaming is a progressive step, statutory recognition of mainstreaming is vulnerable to the problems discussed previously. P.L. $94-142$ has not been immune to restrictive judicial interpretation in the United States. ${ }^{73}$ This is a lesson which should highlight the need for a constitutional right to education. In addition, safeguards built into the system for classifying individuals may be inadequate; furthermore, the "cascade" model that education authorities have constructed to put into ef fect the concept of mainstreaming, may be flawed. ${ }^{74}$

Rather than relying on legislatures and administrators, on inadequate laws and flawed structures, disabled individuals are going to the courts to seek recognition of their educational right to the "least restrictive environment." The main arguments are under s. 15 and s. 7 of the Charter. A recent Nova Scotia case, Elwood, is a good example of the use of the Charter to obtain an appropriate educa. tion for a mentally disabled child and of the interplay between legal and educational concepts.

\section{The Elwood Case: A Study in Mainstreaming}

Luke Elwood is a mentally disabled nine-year-old boy who, for most of his school years attended a segregated special education class in a school some distance from his residence. His parents thought that an integrated setting in the neighbourhood school would be more beneficial, and enrolled him in the local 
grade three class at the beginning of the school year. The school board attempted to move Luke back to the segregated class but an injunction was granted to prevent this. ${ }^{75}$ For the $1986-87$ school year, Luke remained in a class with his ageappropriate peers, receiving extra assistance from an aide. The case was scheduled for trial in June 1987, but was settled the day the trial was to begin. However, as the settlement agreement required court approval, it has precedental value.

The parents made two arguments. First, Luke's placement was a violation of his rights under s. 7 of the Charter. Included in this argument are the contentions that "life, liberty and security of the person" encompasses the right to an appropriate education, that segregation is not an appropriate education, and that the denial of the substantive right took place in a manner not in accordance with fundamental justice. Secondly, Luke's placement was a violation of his s. 15 rights. Included in this argument are the contentions that education is a benefit provided by the state, that the benefit includes more than attendance at a class, that some of the benefits of a regular class were being denied Luke in the segregated class, and that the denial was based on discrimination due to his mental disability.

The s. 15 argument centered around the meaning of equality. Since Luke's attendance at the regular class would entail additional aides, the meaning of equal benefit of the law proposed by the parents emphasized the equal outcomes definition in Sussel and Manley.Casimir's article. Since the court did not give reasons for agreeing to the settlement, it did not comment on whether it accepted this definition. The implications of such a definition are canvassed in the Sussel and Manley-Casimir article. In addition, the s. 15 arguments concerned the benefits of education and whether these were being denied Luke in a segregated class. Indeed the debate about educational theory between Luke's teacher in the integrated class and his former special education teacher is a fascinating aspect of the case.

The school board maintained that they should have the final say about Luke's education. Luke had a right to attend, but Luke's placement was a matter of school board policy. There existed no constitutional right to an appropriate education. However, the school board had an alternative argument. Should education be included under s. 7 , the placement of Luke in a segregated class was done in accordance with fundamental justice. Alternatively, if education was included as a protected right and the denial was not in accordance with fundamental justice, the violation could still be saved under s. 1 .

Certain section 1 arguments can be anticipated regardless of whether the substantive right violated is in s. 7 or s. 15. These section 1 arguments will also lead the courts into the debate about the educational merits and demerits of mainstreaming. The first argument concerns the cost. It will cost more to integrate mentally disabled students than to segregate them. The additional money will have to be raised through increased taxation, or come from another program. This argument is unlikely to succeed. First, the cost differential may not be significant. It may not be a matter of sufficient funds, but sufficient commitment.
Even if the difference is substantial, the significance pales beside the right being upheld. In this regard, Lamer J.'s comments are appropriate:

Section 1 may, for reasons of administrative efficiency successfully come to the rescue of an otherwise violation of s. 7, but only in cases arising out of exceptional conditions, such as natural disasters, the outbreak of war, epidemics and the like. ${ }^{76}$

A second, related argument concerns the lack of facilities and trained teachers. Again, however, this is a matter of commitment. Should the school board make a commitment to integration the facilities and personnel will follow. Indeed, this argument is circular. If the school board makes no commitment, there is no in. centive to acquire adequate facilities, nor reason for teachers to upgrade their qualifications. With no facilities or teachers, the school board can argue that it cannot make the commitment.

A third argument centers around the effect integrating disabled students will have on other students in the class. Ignoring the possible benefits of any interaction, the argument states that these individuals will be slowed down in their academic pursuits. However, this seems to be a limited view of the purposes of education. Moreover, there is little to substantiate this claim. There was no evidence of this problem in respect to Luke Elwood. There may be cases where the presence of a disabled child would interfere with the learning environment for all the students but the burden of proof rests with those who wish to exclude the disabled.

A fourth argument criticizes the socialization aspect of integration. Teachers and students are unwilling to accept mentally disabled individuals into the classroom, and thus isolate them. Instead of the benefits of increased contact, the mentally disabled individual suffers more isolation and a decline in selfesteem. ${ }^{77}$ This argument ignores two factors. First, one does not just throw the child into the classroom without adequate resources and supports. By necessity, there must be planning and preparation. Second, excluding the mentally disabled individual from the classroom because some teachers or students cannot accept them seems to be punishing the innocent party. The fallacy of this argument can be readily seen if one substitutes "negro" or "Jew" for the term "mentally disabled." 78

There seems to be little justification for excluding the disabled, other than the possibility that an integrated setting is less worthwhile than a segregated setting for the individual involved. This is the key, and some would say, the only argument. Would the benefits of integration for the individual involved be outweighed by the harm? As such, it closely approximates the court's approach when exercising its parens patriae jurisdiction. The court should look at the reasons for the rights violation with "... a caution that must be redoubled as the seriousness of the matter increases." 79

The approach should be pragmatic: 
. many of the forces at work, such as that represented by the judicial system, depict the issues surrounding normalization as win-lose, either-or choices, driving out the moderate middle ground position. Those who polarize the situation by promoting either normalization or institutionalization to the complete exclusion of the other do the situation and its complexity a grave injustice. ${ }^{80}$

However, the fundamental difference, the difference which distinguishes cases such as Elwood argued under the Charter, and cases such as Bales ${ }^{81}$ and Rowett ${ }^{82}$ concerns who must bear the burden of proving the benefits of the placement. In the latter cases, it was the parents; in Charter cases it will be the school board.

While the merits of the Elwood case were never argued in court, the strength of each side's case can be determined by the provisions of the settlement agreement. In the end, the Elwood's obtained almost everything they were seeking. One notable exception was costs, which puts significant financial burden on parents and supporters such as the Canadian Association for Community Living.

Luke is to remain in an integrated setting, not only for one year, but at least until he is fifteen. Any change in his placement requires agreement between both parties. In the event of a disagreement, the matter will be sent to arbitration. In any such arbitration, the onus of proving, by "clear and convincing" evidence, that a change in placement is desirable is placed on the party seeking the change. Indeed, the settlement approximates what hopefully will become standard procedure. The child has a right to the regular classroom as the norm. Any change is a violation of that right (under either s. 15 or s. 7). The school board must then jus. tify any departures from the norm subject to strict judicial review.

The Elwood case marks a milestone in the educational rights of the mentally disabled. For the first time, the Charter was used to force a school board to provide a student's right to an appropriate education. Whether the stronger argument was under s. 7 or $\mathrm{s} .15$ or a combination of both remains unanswered. While it is unfortunate that the settlement denied others a reasoned judicial opinion, it should not be forgotten that the P.A.R.C. case, a case that has been called "the cradle of the whole legal rights movement for handicapped people, ${ }^{83}$ was also a court-approved settlement agreement. Luke Elwood has blazed the trail for other mentally disabled students who will follow.

\section{Conclusion}

Sussel and Manley-Casimir begin their article with two quotes that indicate the problems facing the disabled in asserting their right to an appropriate education. It is somewhat ironic that the various education systems in Canada have implemented courses of instruction in human rights in accordance with their commitment under the International Covenant while at the same time denying to the disabled a human right specifically guaranteed in the same Covenant.

In the microcosm of the education system, the courts' decisions regarding the mentally disabled and their right to the most appropriate education will go a long way in sorting out the respective roles of the legislators, administrators, lawyers and judges in the education of children. On a more global basis, determination of the legal status of the mentally disabled and their right to an appropriate education will define what type of society Canadians want and are willing to pay for. Will our society be one of exclusion or inclusion? Will we pay lip service to egalitarian principles while maintaining an elitist policy? Will we allow the majority to prosper at the expense of minorities?

While one might hope that these are mere rhetorical questions, the difficulties experienced by the mentally disabled in the education setting suggest otherwise. Answering these questions will involve a combination of disciplines. Philosophy may provide some answers, sociology others. Economics and political science may have some contribution to make. Education, will be accorded a major role. Should the practioners of these disciplines combine to articulate a clear policy regarding education and the disabled, the discipline of last resort, the law, with its lawyers and judges, need not be involved.

\section{Notes}

1. Elwood v. Halifax County-Bedford District School Board (1987) settlement approved by court order, N.S.S.C.T.D., June 1, 1987

2. L. King, " $\$ 30,000$ extra to educate Luke," The Halifax Chronicle-Herald, June 4, 1987,8 .

3. E.D. Bayda, "Moral Values in Judicial Decision-Making," a paper presented at the Legal Theory Meets Legal Practice Conference, University of Ottawa, May 15-16, Legal Theor 2.

4. J.R. Pennock, "Rights, Natural Rights and Human Rights-A General View," in Pennock and Chapman (eds.), Human Rights (New York: New York University Press, 1981), 6.

5. U.N. Document A/811, 1948, Preamble.

6. U.N.G/A Res. 2200A (XXI), December 16, 1966, Preamble.

7. L. Henkin, "Economic-Social Rights as 'Rights": A United States Perspective," Human Rights Law Journal 2 (1981), 223.

8. Ibid., 224.

9. For an expansion of this concept see A. Roman, "The Charter of Rights: Renewing the Social Contract?"' Queen's Law Journal 8 (1982), 188.

10. Blackstone, in the 1700 s, stated: "So great, moreover, is the regard for private property, that it will not authorize the least violation of it, no not even for the general good of the whole community." Blackstone, Commentaries on the Laws of England, Book I, Chapter I, 139

11. J.R. Pennock, "Thoughts on the Right to Private Property," in Pennock and Chapman (eds ), Property' (New York. New York University Press, 1980), 171. it is important to note that the Charter does not guarantee protection of property interests, 

but the arguments are equally compelling for education as a liberty or security of the
person claim.

12. Board of Education, Island Trees v. Pico, 457 U.S. 853 (1982),

13. Acknowledged by LaForest, J. in $R$. v. Jones, [1986] 2 S.C.R. 284, 296.

14. There are private schools and individual exceptions to state dominated education but there is no doubt that the State has become the major actor on the educational scene

15. F.W. Garforth, Educative Democracy: John Stuart Mill on Education in Society (New York: Oxford University Press, 1980), 177.

16. Pennock, "Rights, Natural Rights and Human Rights," 6 .

17. Gewirth, "The Basis and Content of Human Rights," in Pennock \& Chapman (eds.) Human Rights, 119-120

18. C.A. Wringe, Children's Rights (London, England: Routledge and Kegan Paul Ltd., 1981), 146.

19. J.C. Holt, How Children Fail (New York: Dell Publishing, 1964), 166-167.

20. T. Campbell, "Introduction: Realizing Human Rights," in Campbell et al. (eds.), Human Rights: From Rhetoric to Reality (Oxford, England: Basil Blackwell Inc. 1986), 5.

21. Ibid., 5 .

22. Ibid., 5

23. P. Jones, "Rival Law Reformers," Sol.Jo. 110 (1966), 733.

24. [1976] 2 S.C.R. 200 at 218 quoting Cardozo, The Nature of the Judicial Process (1921), 141.

25. [1976] 2 S.C.R. 200 at 218 quoting Holmes J.in Southern Pacific Co. v. Jensen, 244 U.S. 205 (1917).

26. Enderby Town Football Club v. Football Association, [1971] Ch. 591 (C.A.), 606

27. Reference Re s. 94(2) of the Motor Vehicle Act (B.C.) [1985]2 S.C.R. 486, 496.

28. B. Dickson, "The Judiciary-Law Interpreters or Law-Makers," Manitoba Law Journal 12 (1982), 6. For a more cynical view see I. Duncanson, "Digression on Denning," in P. Robson and P. Watchman (eds.), Justice, Lord Denning and the Constitution (Aldershot: Gower Publishing Co., 1981), 212, who remarked (at 217) that criticism of the judiciary as undemocratic "addresses an absent other which is democratic, responsive and fitted to make political innovations. Legislatures in most social democracies are unlikely candidates for these accolades."

29. President's Committee on Mental Retardation, Silent Minority (Washington, D.C.: U.S. Department of Health, Education and Welfare, 1973).

30. Most reject comments such as Sir J. Donaldston, a judge, gave to a High Court Journalists' Dinner (as quoted in The Times, November 24, 1972) that: "My attitude toward political life is much the same as that of a monk towards sex, nostalgic memories of youthful indiscretion, a frank acknowledgement of its attractions and an unshakable conviction that I could do better than those currently engaged in it."

31. B. Laskin, "What Everyone Should Know About the Supreme Court of Canada," address to the Empire Club, Toronto, March 12, 1981.

32. J. Bentham, Work, vol.5, 235.
33. U.N.G/A Res. 2200A (XXI), December 16, 1966, Preamble.

34. A. Wayne MacKay, "The Charter of Rights and Special Education: Blessing or Curse?" Canadian Journal for Exceptional Children (1987). Forthcoming.

35. Pre-hearing submission by the Halifax County-Bedford School Board, 13.

36. There is strong language to this effect in both the majority judgment of La Forest $\mathrm{J}$. and the dissenting one of Wilson J., in R. v. Jones [1987] 2 S.C.R. 284

37. Constitution Act, 1982 Schedule B of Canada Act (U.K.) 1982, c. 11, s. 52.

38. R. v. Oakes, [1986] 1 S.C.R. 103 at 136.

39. Reference Re s. 94(2) of the Motor Vehicle Act (B.C.), [1985] 2 S.C.R. 486.

40. Serrano v. Priest, $487 \mathrm{p}(2 \mathrm{~d}) 1241$ (1971).

41. San Antonio Independent School District v. Rodrigues, 411 U.S. 1 (1973).

42. However, see J. Cameron, "The Relevance of American Constitutional Law in Charter Adjudication," a paper presented at the Charter Litigation Symposium, University of Toronto, February 28, 1987. Professor Cameron notes, p. 12, that "A parallel exists in the second clause of Article VI of the U.S. Constitution... which has been thought by some to perform just that function."

43. T. van Boven, "The Relations Between People's Rights and Human Rights in the African Charter," Human Rights Law Journal 7 (1986), 183

44. A. Wayne MacKay, "Fairness After the Charter: A Rose by Any Other Name?" Queen's Law Journal 10 (1985), 263.

45. MacKay, "The Charter of Rights and Special Education."

46. Switzman v. Elbling [1957] S.C.R. 285 at 306.

47. Blackstone, Commentaries on the Laws of England, Book 1, Chapter 1, 129.

48. Ibid., Book 1, Chapter 1, 134.

49. Pennsylvania Association for Retarded Children v. Commonwealth of Pennsylvania, 343 F. Supp. 279 (1972), 295.

50. Ibid., 295

51. Pennock, "Rights, Natural Rights and Human Rights," 6.

52. Gewirth, "The Basis and Content of Human Rights," 120

53. H.W. Jones, "Freedom and Opportunity as Competing Social Values: Mill's Liberty and Ours," in C.J. Friedrich (ed.), Liberty (New York: Atherton Press, 1962), 229.

54. Meyer v. Nebraska 262 U.S. 392 (1923), 399

55. [1986] 2 S.C.R. 284 at 301 (majority) and 317 (dissent).

56. Ibid., 318 .

57. Ibid., 318

58. For a more restrictive interpretation of $\mathrm{s} .7$ substantive rights, see $R$. v. Neale (1986), 28 C.C.C. (3d) 345 (Alta. C.A.), quoting Tarnopolsky and Beaudoin, Canadian Charter of Rights and Freedoms Commentary (Toronto: The Carswell Company Ltd., 1982), 270. In Jones, at 317, Wilson J. comments that Tarnopolsky and Beaudoin's definition of liberty is "... much too niggardly...". 
59. E(Mrs.) v. Eve, [1986] 2 S.C.R. 388

60. Ibid., 427.

61. lbid., 434 .

62. Brown v. Board of Education of Topeka, 347 U.S. 483 (1954), 493.

63. U.N.G/A Res. 2200A (XXI), December 16, 1966, Article 13.

64. Education Act R.S.N.S. 1967, c. 81 , s. 74(a).

65. R.S.N.S. 1967 , c. 81 , s. 74 (f). In Ontario, the Education Act, R.S.O. 1980, c. 129 , s. $235(1)(c)$ adds to this list "loyalty," "benevolence," "sobriety," "frugality," and "purity."

66. Brown v. Board of Education of Topeka, 493, as quoted in R. v. Jones [1986] 2 S.C.R. 284 at 297

67. Holt, How Children Fail, 178

68. Ibid., 181

69. Carriere v. Lamont Board of Education, unteported decision of the Alta. Q.B. August 15, 1978

70. M.C. Wang, "Mainstreaming Exceptional Children: Some Instructional Design and Implementation Considerations," Elementary School Journal 81 (1981), 196.

71. E. Zigler and N. Hall, "Mainstreaming and the Philosophy of Normalization," in C.J. Meisel (ed.), Mainstreaming Handicapped Children: Outcomes, Controversies and New Directions (Hillsdale, N.J.: Lawrence Erlbaum Associates, 1986), 1.

72. D. Biklen, Achieving the Complete School: Strategies for Effective Mainstreaming (New York: Teachers College Press, 1985), 28.

73. See, for example, Board of Education of Hendrick Hudson School District v. Rowley, 458 U.S. 176 (1982); Toplianette By Toplianette v. Cronin, 443 N.E. (2d) 29 (1986); Mork v. Grant Wood Area Education Society, 795 F (2d) 52 (1986).

74. M. Forest and E. Lusthaus, "The Kaleidoscope: Challenge to the Cascade." Forthcoming.

75. The use of an interlocutory mandatory injunction, granted by Glube, C.J.T.D., on October 31,1986 , is, in itself, an important legal precedent.

76. Reference Re s. 94(2) of the Motor Vehicle Act (B.C.), [1985] 2 S.C.R. 486.

77. This argument was accepted in Rowett $v$. The Board of Education for the Region of York (1986), unreported, a decision of the Central Region (English) Special Education Tribunal, 48

78. See, for example, the decision in Hickling v. The Lanark, Leeds and Grenville County Roman Catholic School Board (1986), quoting from Stainback et al, "Facilitating Mainstreaming by Modifying the Mainstream," Exceptional Children 52 (1983), 144.

79. E (Mrs.) y. Eve [1986] 2 S.C.R. 427.

80. Zigler and Hall, "Mainstreaming and the Philosophy of Normalization," in C.J. Meisel (ed.); Mainstreaming Handicapped Children (Hillsdale, N.J.: L. Erlbaum Assoc., 1986) 1. See, for example, Reference Re $K, K v$, Public Trustee (1985), 63 B.C.L.R. 145 (C.A.) At 169 , Anderson, J A states: ". the proceedings [10 determine if a mentally disabled child should be sterilized] while adversarial in nature for the purpose of ascertaining the truth... do not constitute a trial in the ordinary sense of that word. This is not a dispute between parties but an inquiry conducted for the purpose of determining what course should be taken in the best interests of Infant $\mathrm{K}$ and others like her."

81. Bales v. School District 23 (Central Okanagan) (1984), 54 B.C.L.R. 203 (S.C.)

82. This tribunal deciison did not consider the Charter. However, the decision is to be reviewed in the courts and the Charter will be a central issue.

83. M. Burgdorf and R. Burgdorf, "Unequal Treatment of Handicapped Persons by Public Education System," in R Burgdorf (ed). The Legal Rights of Handicapped Persons (Baltimore: Paul H. Brookes Publishers, 1980), 90. 